\title{
The 2019 crisis in Chile: fundamental change needed, not just technical fixes to the health system
}

\author{
Claudio A. Méndez ${ }^{1} \cdot$ Scott L. Greer ${ }^{2} \cdot$ Martin McKee $^{3}$
}

Published online: 3 August 2020

(c) Springer Nature Limited 2020

\begin{abstract}
Chile has been viewed as an exemplar of social and economic progress in Latin America, with its health system attracting considerable attention. Eruption of widespread civil disorder marred this image in 2019. We trace the evolution of Chilean health policy and place it in context with developments in other sectors, pensions and education. We argue that much has been achieved, but further progress will necessitate politicians tackling the enduring power of elites that has prevented reform of a two-tier system enshrined in policies of the dictatorship.
\end{abstract}

Keywords Chile $\cdot$ Power $\cdot$ Elites $\cdot$ Health system reform $\cdot$ Democracy

\section{Differing views from near and far}

In the 30 years since Augusto Pinochet's military dictatorship ended, Chile has come to be viewed as an exemplar of political, social, and economic stability in Latin America [1]. Democratic elections have led to peaceful transfers of power, and legislation, the Plan AUGE (Plan de Acceso Universal con Garantías Explícitas en Salud), has expanded health care coverage. Its political parties have been lauded internationally for pragmatism, commitment to the rule of law, and effectiveness in achieving lasting social policy reforms [2]. Many observers, in Chile and worldwide, expressed surprise in late 2019 at eruption of a political and social crisis with large demonstrations accompanied by violence from police and protesters. Impressions of distant observers did not match first-hand experience of life in Chile.

Claudio A. Méndez

claudiomendez@uach.cl

1 Instituto de Salud Pública, Facultad de Medicina, Universidad Austral de Chile, Avenida senador Carlos Acharán Arch, Campus Isla Teja, Valdivia, Chile

2 Global Public Health and Political Science at the University of Michigan, Ann Arbor, MI, USA

3 The London School of Hygiene and Tropical Medicine, London, UK 
Chile's crisis offers an important lesson for others. Successive governments, from the left and right, committed to deliver high-quality health care to all. International observers considered Chilean politicians 'good students' for applying international best practice for inclusive public policies that achieved desired economic, social, and political outcomes, including universal health care (UHC). But something went wrong. We argue that the Chilean experience shows technical measures cannot succeed if bolted to a dysfunctional structure dominated by entrenched power of groups that resist reform.

\section{The crisis and its origins}

The roots of the crisis that erupted in 2019 are much older. Chile legislated a national health service in 1952 promoted by then Senator Salvador Allende, a physician and a socialist - a step toward universal health coverage. That reform combined disparate programs that covered the poorest $70 \%$ of the population. It did not incorporate programs for the military, police, civil servants, and salaried private employees [3]. President Eduardo Frei Montalva, a Christian Democrat elected in 1964, implemented social reforms, progressive taxation and large investments in health care infrastructure [4] accompanied by marked improvements in health outcomes. Both the left and right criticized him-for doing too little or too much. Allende succeeded him in 1970, elected on an avowedly Marxist manifesto [5]. His reforms included strengthening health services for the poor. Powerful industrialists, foreign investors, and physicians in private practice immediately attacked [6]. A 1973 coup replaced him with a military dictatorship led by General Augusto Pinochet Ugarte. This government radicalized economic policy based on ideas from Milton Friedman and the Chicago school of economics, described by the Canadian author Naomi Klein as a "shock doctrine" [7]. It destroyed many institutions in place since the 1950s and transferred large areas of state activity to the private sector [8]. We show the effects by examining three sectors, pensions, education, and health.

\section{Pensions}

The Pinochet regime privatized pensions [9]. It required workers to contribute $10 \%$ of monthly wages [10] to the Pension Fund Administrators (Asociación de Fondos de Pensiones) to promote individual responsibility. Pension fund administrators benefitted most, by charging excessive management fees and widening inequality among beneficiaries [11].

\section{Education}

The regime transferred schools from the ministry of education to local authorities and instated a voucher scheme-moving away from funding based partially on need. Families could use vouchers for public or private schools; the money followed the child. 
Subsequent analysis showed no improved educational standards but an increase in social stratification [12].

\section{Health}

The Pinochet regime did not change the health system initially, though it progressively cut funding. Then in 1979 it replaced the Servicio Nacional de Salud with the Sistema Nacional de Servicios de Salud, and replaced a health fund, the Servicio Médico Nacional de Empleados (SERMENA) with a new one, the Fondo Nacional de Salud (FONASA). Employees contributed 7\% of their gross income. The fund also covered unemployed persons and certain pensioners. But, as with schools, Chileans could, and the regime encouraged them to, opt out and obtain coverage from a highly subsidized network of private insurers, the Instituciones de Salud Previsional (ISAPRE). ISAPRE provided access to private facilities, thereby creating a two-tier health system. These were much more expensive and were seen as of higher quality than those affiliated to the FONASA system [13].

Next came a transition to democracy with a succession of governments from the center-right, initially (Patricio Aylwin, 1990-1994 and Eduardo Frei, son of the previous president, 1998-2000) and later the center-left (Ricardo Lagos, 2000-2006 and Michel Bachelet, 2006-2010, 2014-2018). They implemented reforms, including of taxation and social welfare. President Bachelet reformed pensions in the late 2000s to help the poorest $60 \%$ of the population. The reformed pensions did not depend on contribution history, but left core elements of the privatized scheme in place [14]. Education policies from the dictatorship also persisted despite a 2006 "Penguin Revolution", when high school students revolted against the segregation of public and private schools and a 2011 revolt by university students demanding an end to the free-market approach to education [15].

In the health sector, President Lagos seemed to make substantive reforms in Plan $A U G E$, enacted in 2004. This required timely access to high-quality health care by public and private providers, along with financial protection, for a list of health conditions [16-18]. The initial list of 25 health conditions expanded incrementally to the current 85. President Sebastián Piñera announced inclusion of another 5 at the onset of the crisis of 2019. But he also left in place the inherited structures. He did not tackle widespread co-payments required of all except some groups (such as the unemployed, FONASA groups A and B). All others [ISAPRES and FONASA (Groups C and D)] pay from 0 to $20 \%$ of the total price of services [19].

The continued strength of conservative forces and, especially the military in the early years of democratic governments, represented a political consensus favoring minimal reforms without dismantling fundamental power structures [20]. 


\section{The crisis of 2019}

Protests, which by of July 2020 were no longer on the streets but had merged into popular criticism of the government's pandemic response, began on 17 October 2019 when students jumped turnstiles in the Santiago subway system to protest against a 30 Chilean Peso (approximately 4 US cents) fare increase during peak hours [21]. The increase was small but imposed during growing discontent with overcrowded carriages and already high fares [22]. Protests soon escalated. Large crowds gathered in peaceful rallies to demand major changes to social protection policies including pensions, education, and health. Then violence erupted; the police were unable to control the situation, despite deploying considerable violence themselves. The government declared a State of Emergency on 19 October 2019, giving the Armed Forces responsibility to restore order in the capital [23]. The use of troops evoked the history of brutality by the Chilean dictatorship.

Deploying the military did not restore calm. On Saturday, 20 October 2019, the general in command declared a curfew from $10 \mathrm{pm}$ to $7 \mathrm{am}$, the first during democratic rule in Chile [24]. Violence, including human rights violations, mushroomed [25]. On 23 October, President Sebastián Piñera responded to growing demands with an "agenda social" (social agenda), measures to alleviate concerns about the health system including a ceiling on out-of-pocket spending, an insurance plan to cover drugs, and an agreement between the Central Nacional de Abastecimiento (National Centre for Supply) and the most important private drugstore companies to reduce the price of medicines for those who obtained health care from public providers [26].

Despite this "agenda social", peaceful rallies and violent protests continued, now nationwide. On 15 November representatives of almost all Chile's political parties represented in the bicameral Congress signed The Agreement for Peace and a New Political Constitution. It includes provisions for referenda, a first scheduled for 26 April 2020-then postponed to October because of the COVID-19 pandemic. It will ask Chileans if they agree to creation of a new constitution; and if so, who should prepare it? A new constitution would replace the one left by the Pinochet regime, which prioritized a market economy over social protection [27]. Piñera's government simultaneously escalated repressive measures. On 21 and 26 November 2019, Amnesty International and Human Rights Watch published reports on human rights violations in Chile since the start of civil disorder. Both reports included evidence of excessive force by police during protests - including use of shotguns loaded with rubber pellets blamed for more than 220 eyes injuries [28, 29]. The Inter-American Commission for Human Rights and United Nations Human Rights Office recommended changes to police practices [30, 31].

\section{Chile's health system: a success story?}

Chile had been making progress economically and socially despite the lack of fundamental reforms. That is why the eruption of widespread public discontent surprised many. Chile boasts the highest per capita Global Domestic Product (GDP) 
in South America, and, in 2010, was the first country from that continent to join the Organization for Economic Cooperation and Development (OECD). Social progress was especially apparent in the health sector. In 2010, the World Health Report described Chile as an "in the right way country", highlighting its progress to Universal Health Coverage (UHC) [32].

Early analyses of implementation of the Plan AUGE, intended to improve access to facilities near peoples' homes, reduced waiting times, improved quality, and caps on co-payments (maximum $20 \%$ of the price and no more than one month's family income for the family in a year), reported a 30\% an increase in use of health services for conditions such as type 2 diabetes and hypertension [33] and improved survival after acute myocardial infarctions [34].

President Michelle Bachelet extended health coverage further during her second term, enacting the 2015 Ley Ricarte Soto. It established Financial Protection System for High-Cost Diagnostics and Treatments, not previously covered, and diagnostic investigations and treatments for oncological, immunological, and rare diseases [35]. The Law also established a commission to set priorities. It was made up of two members of patient organizations and twelve renowned specialists in public health, medicine, bioethics, economy, health law, and drugs named by the Ministry of Health [35].

While attribution of changes in health outcomes to a particular policy is always difficult, there are signs that these policies have improved access to health care facilities. The Health Access and Quality Index, part of the Global Burden of Disease program, measures deaths that should not occur with timely and effective care, adjusted for the risk profile of the population [36]. Despite starting at similar levels, Chile pulled ahead of Argentina and Uruguay after 2000. Use of health services for conditions covered by AUGE increased, in some cases dramatically [37].

\section{Problems remain}

Health reform has been a high priority for Chile's leaders in since Pinochet's rule. Wide inequalities remain and benefits from reform have flowed unevenly to groups in the population [38-40]. Vásquez and colleagues showed that service utilization increased for all groups and inequalities narrowed, but by 2009 a pro-rich pattern of consultations with dentists, specialists, and other physicians persisted [38], findings that are supported by research on measures such as specialty visits, laboratory tests, and hospitalization. All demonstrate concentration of utilization by the most affluent households, and of emergency visits by those with fewest resources $[41,42]$. Patients report continuing barriers to care, especially co-payments. Out-ofpocket spending is high by OECD standards [43] and many households experience catastrophic costs [44]. In 2018 Chile's health expenditure per capita was US\$2182, one of the lowest among OECD countries; it has grown rapidly, at a rate among the highest of OECD countries [45]. As a percentage of GDP, spending increased from 6.8 in 2010 to 9.0 in 2019 [46]. Polling reveals persisting disaffection with health care $[47,48]$. Wide inequalities persist in availability, affordability, and utilization of health services [49-51]. Death rates among those waiting for treatment of conditions 
not covered by AUGE have increased [52]. Chile's economic system has made it one of the most economically unequal countries in the world, with a Gini coefficient of 0.49 [53]. Wealth inequality is harder to measure [54] but seems to be even higher, with the share of GDP owned by billionaires the highest in the world (excluding tax havens) [55].

\section{Where does the power lie?}

The commitment of successive Chilean governments to implement change is not in doubt but they have been unable to make major changes to the two-tier system created by the dictatorship [13]. In the health sector, powerful private insurers remain unscathed [56]. Silva argued that a coalition of business leaders and landowners influenced policies of the Pinochet regime and their power persisted after the democratic transition. The legacy amounts to an implicit agreement between them and subsequent governments to permit democracy, but without challenging much of the status quo [57]. Chile is not unique in this; elsewhere fundamental political and economic reforms have left existing power relationships largely intact. Notable examples include the transition from communism in Europe, where many of the previous leaders transformed overnight into "democrats" [58] and the rapid recovery of slave owning families in the Confederate states after the American civil war [59]. Acemoglu and Robinson developed an equilibrium model to explain this, in which they distinguish the "elite" from the "citizens". The former hold de facto power even though the latter have de jure power [60]. They show that changes in de jure power, such as those brought about by a transition to democracy, can be offset by changes in de facto power, especially where the stakes are high for elites.

\section{Conclusion}

The Italian writer Giuseppe Tomasi di Lampedusa, in his novel The Leopard, described an aristocratic Sicilian family finding ways to retain influence during the Italian Risorgimento, delivering the famous quotation: "everything must change so that everything can stay the same" [61]. On the surface, everything has changed in Chile. But as to the distribution of power, everything has stayed the same. The recent crisis drew attention to weaknesses in the health system but, if our analysis is correct, to be effective the response will not just be a technical fix but a fundamental reassessment. Recently, Crispi and colleagues wrote: "Chile must decide if the time has come for a profound structural change, based on a different set of political and ethical principles" [62]. We agree.

\section{References}

1. Barton JR, Murray WE. The end of transition? Chile 1990-2000. Bull Latin Am Res. 2002;21(3):329-38. 
2. Huber E, Pribble J, Stephens JD. The Chilean left in power. In: Weyland K, Madrid R, Hunter W, editors. Leftist governments in Latin America: successes and shortcomings. New York: Cambridge University Press; 2010. p. 77-97.

3. Roemer MI. National health systems of the world: Volume 1 The countries. New York: Oxford University Press; 1993.

4. Frei E. The political realities of health in a developing nation. Bull $\mathrm{N} Y$ Acad Med. 1975;51(5):580-90.

5. Tedeschi SK, Brown TM, Fee E. Salvador Allende: physician, socialist, populist, and president. Am J Public Health. 2003;93(12):2014-5.

6. Viveros-Long A. Changes in health financing: the Chilean experience. Soc Sci Med. 1986;22(3):379-85.

7. Klein N. The shock doctrine. New York: Henry Holt and Company; 2008.

8. Borzutzky S. From Chicago to Santiago: neoliberalism and social security privatization in Chile. Governance. 2005;18(4):655-74.

9. Buchholz GJ, Coustasse A, Silva P, Hilsenrath P. The Chilean pension system at 25 years: the evolution of a revolution. J Econ Issues. 2008;42(3):633-47.

10. Hyde M, Borzutzky S. Chile's, "Neoliberal" retirement system? Concentration, competition, and economic predation in "Private" pensions. Poverty Public Polic. 2015;7(2):123-57.

11. Borzutzky S, Hyde M. Chile's private pension system at 35: impact and lessons. J Int Comp Soc Policy. 2016;32(1):57-73.

12. Hsieh C-T, Urquiola M. The effects of generalized school choice on achievement and stratification: evidence from Chile's voucher program. J Public Econ. 2006;90(8-9):1477-503.

13. Rotarou ES, Sakellariou D. Neoliberal reforms in health systems and the construction of long-lasting inequalities in health care: a case study from Chile. Health Policy. 2017;121(5):495-503.

14. Borzutzky S. You win some, you lose some: pension reform in bachelet's first and second administrations. J Polit Lat Am. 2019;11(2):204-30.

15. Cabalin C. Neoliberal education and student movements in Chile: inequalities and malaise. Policy Futures Educ. 2012;10(2):219-28.

16. Bossert TJ, Leisewitz T. Innovation and change in the Chilean Health System. N Engl J Med. 2016;374(1):1-5.

17. Bustamante AV, Mendez CA. Health care privatization in Latin America: comparing divergent privatization approaches in Chile, Colombia, and Mexico. J Health Polit Policy Law. 2014;39(4):841-86.

18. Barrera CR, Negron CP, Barria RM, Mendez CA. Rights and duties policy implementation in Chile: health-care professionals' perceptions. Health Expect. 2016;19(5):1062-70.

19. Sojo A. Health benefits guarantees in Latin America: equity and quasimarket restructuring at the beginning of the Millennium Mexico: CEPAL. 2006.

20. Inzunza J, Assael J, Cornejo R, Redondo J. Public education and student movements: the Chilean rebellion under a neoliberal experiment. Br J Sociol Educ. 2019;40(4):490-506.

21. Navia P. Chile's riots: frustration at the gate of the promised land Americas Quarterly. 2019.

22. Garnham JPAN. Why Chile's massive protests started with the metro. City Lab; 2019. https://www. citylab.com/transportation/2019/10/chile-protest-santiago-metro-public-transit-fare-inequality /600874/. Accessed 16 Jan 2019.

23. Reuters. In Chile, a deadly weekend of arson, riots and armed forces as discontent rises. NBC News. 2019.

24. Laing A, Donoso, G. Chile army declares curfew, president reverses fare hikes after unrest. Reuters. 2019.

25. Franklin J. Hundreds shot and beaten as Chile takes to the streets. The Guardian. 2019.

26. Fraser B. Violent protests in Chile linked to health-care inequities. Lancet. 2019;394(10210):1697-8.

27. Bartlett J. 'The constitution of the dictatorship has died': Chile agrees deal on reform vote The Guardian. 2019.

28. International A. Chile: deliberate policy to injure protesters points to responsibility of those in command 2019.

29. Human Rights Watch. Chile: police reforms needed in the wake of protests. 2019.

30. Inter-American Commission on Human Rights. IACHR condemns the excessive use of force during social protests in Chile, expresses its grave concern at the high number of reported human rights violations, and rejects all forms of violence. 2019. 
31. United Nations Human Rights. UN Human Rights Office report on Chile crisis describes multiple police violations and calls for reforms: United Nations. 2019.

32. World Health Organization. The World Health Report. Health systems financing: the path to universal health coverage. Geneva: World Health Organization; 2010. p. 2010.

33. Bitran R, Escobar L, Gassibe P. After Chile's health reform: increase in coverage and access, decline in hospitalization and death rates. Health Affair. 2010;29(12):2161-70.

34. Nazzal C, Frenz P, Alonso FT, Lanas F. Effective universal health coverage and improved 1-year survival after acute myocardial infarction: the Chilean experience. Health Policy Plan. 2016;31(6):700-5.

35. Charvel S, Cobo F, Larrea S, Baglietto J. Challenges in priority setting from a legal perspective in Brazil, Costa Rica, Chile, and Mexico. Health Hum Rights. 2018;20(1):173-84.

36. GBD Healthcare Access and Quality Collaborators. Measuring performance on the Healthcare Access and Quality Index for 195 countries and territories and selected subnational locations: a systematic analysis from the Global Burden of Disease Study 2016. Lancet (London, England). 2018;391(10136):2236-71.

37. Paraje G, Vásquez F. Health equity in an unequal country: the use of medical services in Chile. Int J Equity Health. 2012;11:81.

38. Vasquez F, Paraje G, Estay M. Income-related inequality in health and health care utilization in Chile, 2000-2009. Rev Panam Salud Publ. 2013;33(2):98-U187.

39. Borzutzky S. Health in Chile: is the government doing everything it can to achieve social justice? Med Law. 2008;27(3):645-59.

40. Núñez A, Chi C. Equity in health care utilization in Chile. Int J Equity Health. 2013;12(1):58.

41. Nunez A, Manzano CA, Chi C. Health outcomes, utilization, and equity in Chile: an evolution from 1990 to 2015 and the effects of the last health reform. Public Health. 2020;178:38-48.

42. Vera AC, Lavin FV, Paraje G. Inequality and inequity in the use of medical services in Chile, by age group, 2000-2011. Rev Panam Salud Publ. 2014;36(3):171-8.

43. Dintrans PV. Out-of-pocket health expenditure differences in Chile: insurance performance or selection? Health Policy. 2018;122(2):184-91.

44. Koch KJ, Pedraza CC, Schmid A. Out-of-pocket expenditure and financial protection in the Chilean health care system: a systematic review. Health Policy. 2017;121(5):481-94.

45. Organisation for Economic Co-operation and Development. Health at a Glance 2019: OECD Indicators. 2019.

46. Health expenditure and financing [database on the Internet]. https://stats.oecd.org/Index .aspx?ThemeTreeId=9\#. Accessed 17 July 2020.

47. Kim MK, Blendon RJ, Benson JM. What is driving people's dissatisfaction with their own health care in 17 Latin American countries? Health Expect. 2013;16(2):155-63.

48. Levitsky S. Democratic survival and weakness. J Democr. 2018;29(4):102-13.

49. Frenz P, Delgado I, Kaufman JS, Harper S. Achieving effective universal health coverage with equity: evidence from Chile. Health Policy Plan. 2014;29(6):717-31.

50. Paraje G, Vasquez F. Health equity in an unequal country: the use of medical services in Chile. Int J Equity Health. 2012;18:11.

51. Rotarou ES, Sakellariou D. Inequalities in access to health care for people with disabilities in Chile: the limits of universal health coverage. Crit Public Health. 2017;27(5):604-16.

52. Martinez DA, Zhang HX, Bastias M, Feijoo F, Hinson J, Martinez R, et al. Prolonged wait time is associated with increased mortality for Chilean waiting list patients with non-prioritized conditions. BMC Public Health. 2019;19:233.

53. Hartmann D, Guevara MR, Jara-Figueroa C, Aristaran M, Hidalgo CA. Linking economic complexity, institutions, and income inequality. World Dev. 2017;93:75-93.

54. Scheve K, Stasavage D. Wealth Iniequality and democracy. Annu Rev Polit Sci. 2017;20:451-68.

55. Flores I, Sanhueza C, Atria J, Mayer R. Top incomes in Chile: a historical perspective on income inequality, 1964-2017. Rev Income Wealth. 2019. https://doi.org/10.1111/roiw.12441.

56. Martinez-Gutierrez MS, Cuadrado C. Health policy in the concertacion era (1990-2010): reforms the chilean way. Soc Sci Med. 1982;2017(182):117-26.

57. Silva EB. The state and capital in Chile: business elites, technocrats, and market economics. London: Routledge; 2019.

58. Pakulski J, Kullberg JS, Higley J. The persistence of postcommunist elites. J Democr. 1996;7(2):133-47. 
59. Ager P, Boustan LP, Eriksson K. The intergenerational effects of a large wealth shock: white southerners after the civil war. Washington DC: National Bureau of Economic Research; 2019.

60. Acemoglu D, Robinson JA. Persistence of power, elites, and institutions. Am Econ Rev. 2008;98(1):267-93.

61. Lampedusa G. The leopard. London: Pantheon; 1958.

62. Crispi F, Cherla A, Vivaldi EA, Mossialos E. Rebuilding the broken health contract in Chile. Lancet (London, England). 2020;395(10233):1342.

Publisher's Note Springer Nature remains neutral with regard to jurisdictional claims in published maps and institutional affiliations.

Claudio A. Méndez , MPH, is associate professor of Health Policy at the Instituto de Salud Pública, Facultad de Medicina, Universidad Austral de Chile, Valdivia, Chile.

Scott L. Greer , PhD, is professor of Health Management and Policy, Global Public Health and Political Science at the University of Michigan, Ann Arbor, Michigan, USA.

Martin McKee , MD, DSc, is professor of European Public Health at The London School of Hygiene and Tropical Medicine, London, United Kingdom. 